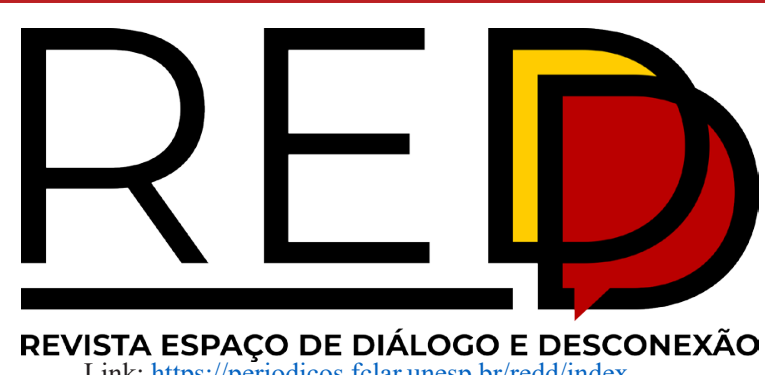

REVISTA ESPAÇO DE DIÁLOGO E DESCONEXÃO

CONCEPCOOES PROGRESSISTAS E CULTURALISTAS DO ESPACO SOCIAL: A DIMENSÃO DOS PROJETOS E DOS PLANOS PARA AS CIDADES BRASILEIRAS DA PRIMEIRA METADE DO SÉCULO XX ${ }^{1}$

TOLEDO, Rodrigo Alberto ${ }^{2}$

IID ORCID: https://orcid.org//0000-0001-6232-4703

Autor para correspondência e-mail: ro-toledo@hotmail.com.br

\section{Palavras-chave RESUMO}

Democracia

Participação

Políticas Públicas

Políticas Públicas

O objetivo desse artigo é mapear as concepçoes urbanísticas que, a partir do final do século XIX, recriaram o modelo de intervençăo na malha urbana, principalmente, das cidades industriais. O modelo de cidade e de intervenção que se consolida no periodo que se estende do final do século XIX até meados do século XX, nas aqui denominadas correntes progressista e culturalista, serviu de referenencia para os pensadores urbanisticos para dar resposta à problematica urbana, fruto, no caso brasileiro, de um acelerado desenvolvimento propulsado pela ampliação da presença da indústria nesses e aplicar normas de ocupacão lícita do solo é captada por um conjunto de urbanistas brasileiros, sendo que um dos expoentes no estado de São Paulo será Luiz Ignácio Romeiro de Anhaia Mello, aqui denominado como Anhaia Mello que passou a (re)significar os modelos e propostas de cidade à realidade brasileira. $\mathrm{O}$ pensamento reflexivo sobre problemática urbana, desenvolvido por Anhaia Mello, é o produto amalgamado das propostas elaboradas por urbanistas localizados por Choay (2013) nas correntes progressista e culturalista de cidade.

Keywords

Urbanism

Public Policis

Directive Plan

Palabras clave

Democracia

Participación

Urbanismo

Políticas Públicas
Plane Director

\section{AbSTRACT}

Progressive AND CULTURALIST URBAN CURRENTS: THE DIMENSION OF PROJECTS AND PLANS FOR BRAZILIAN CITIES IN THE FIRST HALF OF THE 20TH CENTURY

The objective of this article is to map the urban conceptions that, from the end of the 19th century, recreated the model of intervention in the urban network, mainly of industrial cities. The model of city and intervention that consolidates in the period that extends from the late nineteenth century to the mid-twentieth century, in the named progressive and culturalist currents, served as a reference for urbanistic thinkers to respond to urban problems, in the Brazilian case, an accelerated development propelled by the expansion of the presence of industry in these contexts. In these terms, the need for empowerment of municipal public institutions that could create and apply standards of lawful land occupation is captured by a group of Brazilian urbanists, one of the exponents in the state of São Paulo will be Luiz Ignácio Romeiro to the Brazilian reality The reflexive thinking about the urban problem developed by Anhaia Mello, is the amalgamated roduct of the proposals elaborated by urbanists located by Choay (2013) in the progressive and culturalist chains of the

\section{RESUMEN}

LAS CORRIENTES DE PLANIFICACIÓN URBANA CULTURALISTA Y PROGRESIVA: LA DIMENSIÓN DE LOS PROYECTOS Y PLANES PARA LAS CIUDADES BRASILEÑAS DE LA PRIMERA MITAD DEL SIGLO XX

La intención de este artículo es reconducir el debate para el tema de la gestión democrática de las ciudades, un imporque diferencien la planificación de gestión. Se pretende demostrar que la planificación y la gestión no son términos cambiables, pues poseen referenciales temporales distintos y se refieren a diferentes tipos de actividades. Las análises elaboradas en el presente artículo están disponibles en la base de datos bibliográficos, lecturas y interpretaciones de libro y periódicos, a partir de la calificación de una pregunta: ‘cómo llegar a la democratización del proceso de decisiones en la formulación de políticas públicas urbanas? Sin embargo, el procedimiento de análisis del proceso de elaboración de Plane Director de Araraquara identificó el desafío principal para una tarea de planeamiento de la gestión administrativa utilizando metodologías democráticas participativas.

O presente artigo é uma versão adaptada e ampliada do Capítulo 2 - As correntes urbanísticas progressista e culturalista, publicado no livro "Do projeto ao plano: a corrente urbanística paulista", São Carlos, São Paulo: Editora RiMa, 2017

"Pós-doutorando em Ciências Sociais, Doutor em Ciênncias Sociais - Unesp-Fclar e USAL - CEB y Instituto de Iberoamericana, Espanha e Mestre em Sociologia pela Unesp-Fclar. Professor no Programa de Pós-Graduação em Ciências Sociais e no Departamento de Sociologia - Unesp/FCLAt.
A INTRODucióo

位 no meio rural, como a drenagem dos campos, tendo como beneficiário dessas ações um desenvolvimento urbano intenso.

Segundo Choay (2013), o primeiro teatro desse movimento foi a Grã-Bretanha, que, em 1801, apresentou em seus recenseamentos uma mudança sensível no perfil de sua população, que passou a ser majoritariamente urbana. Na Europa, os países que capitanearam esse processo foram a França e Alemanha, a partir dos anos de 1830. A principal metrópole inglesa, Londres, apresenta números significativos, em seus recenseamentos, a cidade “... passa de 864.845 habitantes em 1801..." para "1.873.676 em 1841 e 4.232.118 em 1891: em menos de um século, sua população praticamente quintuplicou" (CHOAY, 2013,p. 3). Evidentemente, este processo não ficou restrito à metrópole londrina, pois, como uma reação em cadeia, fez com que o número das cidades, com mais de 100 mil habitantes, passasse de duas para trinta.

Do ponto de vista da malha urbana, uma nova ordem irá impor adaptações da cidade à sociedade que as habitavam. As velhas cidades europeias são compelidas a romper com seus velhos quadros, da cidade medieval e da cidade barroca, para se adaptarem a esse ciclo intenso de adensamento populacional, que demandou, por sua vez, intervenções estratégicas, como aquelas adotadas por Haussmann ${ }^{3}$ para adaptar Paris às exigências sociais e econômicas do Segundo Império Napoleônico.

Para Choay (2013), essa nova ordem pode ser organizada em um conjunto de características. Em primeiro lugar, a racionalização das estruturas urbanas voltadas para a comunicação (mobilidade) com a criação de grandes artérias para a intensificação dos contatos e a aceleração dos transportes, uma necessidade evidente em um contexto de contínuo processo de periferização das cidades. Em segundo, a especialização de setores, os quarteirões, que se voltaram para práticas comerciais, religiosas, financeiras e para a residência, acentuando a hierarquia dos espaços urbanos que refletiam as desigualdades sociais de classe. Novos órgãos passam a compor esse cenário e que, por seu gigantismo, mudaram o formato da cidade: grandes mercados, grandes lojas, grandes hotéis, prédios para alugar

O estudo da cidade, no século XIX, absorve esses movimentos descritos anteriormente, basicamente em duas vertentes. Na primeira, observam-se os fatos isoladamente a partir de uma sistematização quantitativa Assim, a estatística - incorporada pela sociologia - é a ferramenta aplicada para a construção de modelos interpretativos, que pudessem desvendar "as leis de crescimento das cidades" (CHOAY, 2013, p.22). Na Europa e nos EUA, os precursores dessa corrente de pensamento procuraram entender o fenômeno de desenvolvimento urbano espontâneo em contraposição à vertente "organizada" que o urbanismo projeta sobre si.

Nesses primórdios do século XIX, tais pensadores procuravam situar o fenômeno do desenvolvimento urbano espontâneo em uma rede de causa e efeito, com o fito de dissipar preconceitos que diziam respeito às "patologias" sociais urbanas relativas ao desenvolvimento físico da cidade industrial. Destarte, a cidade, ou melhor, o crescimento urbano gerou cidades com patologias metaforizadas, como câncer, tumor, congestionada e degradada. Outro conjunto de pensadores têm suas críticas inspiradas por sentimentos humanitários, compostos por: dirigentes da Igreja, principalmente médicos e higienistas, que tornam público, fundamentados em fatos e números, a condição de deterioramento físico e moral, no qual estão submetidos os proletariados urbanos. O diálogo estabelecido por este conjunto de pensadores com a sociedade dar-se-á por meio da publicação de artigos em jornais e revistas e que, no limite, impulsionou na Inglaterra, a criação das denominadas Comissões Reais de Pesquisas e Higiene pelo Parlamento, que, por sua vez, publicarão importantes relatórios, que contribuíram para a criação do arcabouço jurídico sobre trabalho e habitação.

$\mathrm{Na}$ segunda vertente, os pensadores que ganharam maior relevo foram os políticos. As análises sobre a interrelação ente o poder público e econômico apontaram pistas importantes para análise das desigualdades de classe que tomavam forma no desenho urbano das grandes metrópoles industriais. Engels, especificamente, ao formular análises importantes sobre o proletariado inglês, na obra "A situação da classe trabalhadora na

Georges-Eugène Haussmann (Paris, 1809 - Paris, 1891), conhecido como Barão Haussmann, foi prefeito de Paris e entre 1853-1870, responsável pela sua reforma. A cidade de Paris adentra ao século XX com a forma que the foi dada por Haussmann. Bairros inteiros foram demolidos dentro da lógica da reforma urbana estratégica em que "... as velhas vielas estreitas, insalubres, imbricadas, nas quais viviam encurraladas..." centenas de pessoas deveriam passar por um saneamento. (BENJAMIN, 2015). 
Inglaterra", deu o próprio contorno da sociologia urbana. As amplas pesquisas documentais e de campo, feitas por meses a fio, nos "Slums" de Londres, Edinburgo, Glasgow e Manchester, foram sistematizadas e, como aponta Choay (2013), utilizadas por Marx, em "O Capital".

Aliados a esse grupo de pensadores, podemos ainda citar Matthew Arnold e Fourrier, Proudhon, Carhyle e Ruski, que se somam ao coro para denunciar o degradante, insalubre e violento habitat do trabalhador, comparando-o, inclusive, a covis, que denunciam as grandes distâncias percorridas até o local de trabalho, os lixões amontoados pelas ruas e a ausência de áreas públicas, como jardins nos bairros. Sem dúvida, essas análises compõem um quadro maior, qual seja a crítica global da sociedade industrial e a presente necessidade

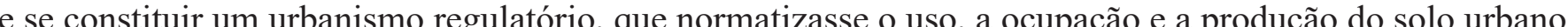

Excluindo-se Marx e Engels, poucos foram os pensadores, deste final do século XIX, que conectaram com lucidez a problemática da cidade industrial à estrutura econômica e política que aplaca a organização do espaço urbano dentro da lógica capitalista. Em outros termos, o processo de mercantilização do espaço urbano - destinado à habitação, sociabilidade, consumo e lazer -, implicou o desaparecimento da antiga (Medieval Barroca) ordem urbana e o surgimento de uma ordem nova.

$\mathrm{O}$ pensamento de Anhaia Mello situa-se nesse momento em que os pensadores urbanísticos recriaram o modelo de intervenção na malha da cidade para dar resposta à problemática de uma metrópole, em um país periférico, que careceu - ao longo de seu processo de desenvolvimento acelerado - de um poder público que criasse normas para a ocupação lícita do solo. E é essa necessidade, captada por Anhaia Mello, que conduzirá suas reflexões a um diálogo com, fundamentalmente, dois momentos do desenvolvimento do pensamento urbanístico, assim classificados por Choay (2013): o urbanismo progressista e o urbanismo culturalista.

Antes, no entanto, de passarmos a essa etapa, primeiramente é necessário definir o termo urbanismo como ciência e teoria da localização humana. Esse conceito tem a finalidade de proporcionar instrumental para análise da expansão da sociedade industrial (do final do século XIX) e que carrega em si um caráter reflexivo e crítico. Assim, como os demais campos das ciências sociais aplicadas, o urbanismo não questiona a necessidade das soluções que preconiza, mas objetiva criar procedimentos metodológicos para que sejam produzidas interpretações universalizadas e científicas. Ao partir desse pressuposto, o urbanismo delimitou um campo de pesquisa, que é a cidade e suas variantes, que se propõe a resolver um problema, qual seja, o planejamento da cidade maquinista, que surgia antes de sua criação, mais precisamente, nas primeiras décadas do século XIX, quando a sociedade industrial iniciou a ter um entendimento dos impactos de suas transformações e, por conseguinte, a questioná-las (CHOAY, 2013)

O urbanismo, portanto, pode ser interpretado a partir de um conjunto periodicizado de etapas, que proporcionará, por sua vez, a reconfiguração de um quadro de referência, capaz de situar os problemas urbano e, consequentemente, as diversas soluções formuladas. Essa opção de abordagem permitirá cotejar as correntes urbanísticas com os problemas aos quais thes foram impostos e, por conseguinte, delinearmos o process de ressignificação das propostas de soluções com a estrutura dos encaminhamentos, conduzidos por Anhaia Mello, ao tratar do desenvolvimento urbano nos pequenos e grandes centros.

No entanto, por uma questão de recorte temporal, orientado pelo nosso projeto de pesquisa - a sistematização dos planos diretores elaboradas no Estado de São Paulo a partir de 1950 pelo Centro de Pesquisa e Estudos Urbanísticos, CEPEU -, analisaremos as propostas urbanísticas a partir do desenvolvimento das escolas, classificadas por Choay (2013) e que, aqui, daremos os nomes de a corrente urbanística progressista e corrente urbanística culturalista. Em cada uma das escolas do urbanismo, daremos destaque aos seus principais expoentes para analisarmos, a posteriori, os eixos interpretativos nucleares em nosso debate sobre o processo de formulação dos Planos Diretores no Estado de São Paulo: a reconstrução do processo intelectual-formativo das referências utilizadas por Anhaia Mello na formulação de sua proposta urbanística e a identificação, nas histórias das ideias, do respaldo conceitual-metodológico que serviu de plataforma para a elaboração de inúmeros planos diretores durante o período de desenvolvimento das atividades do CEPEU4 ${ }^{4}$. (TOLEDO ${ }^{4} \mathrm{~A}$ Lei no ${ }^{\circ} .233$, de 27 de outubro de 1955, que dispõe sobre o regulamento da Faculdade de Arquitetura e Urbanismo da Universidade de São Paulo, criada por sua vez, pela Lei $\mathrm{n}^{\circ} 104$, de 21 de junho de 1948, orientava o ensino e a pesquisa em planejamento territorial nesta Faculdade. Segundo a lei, o curso de Pós-Graduação em Urbanismo seria desenvolvido em dois anos pelo Centro de Pesquisa e Estudos Urbanísticos (CEPEU) anexo à Cátedra de Urbanismo. A atuação do CEPEU, como órgão de assessoramento, via convênio com o Departamento de Obras Sanitárias do Estado de São Paulo, para a elaboração dos planos diretores das Estâncias que se iniciam em 1957, sob direção de Luiz Ignácio Romeiro de Anhaia Mello (1957-1961). O CEPEU encerra suas atividades no ano de 1972, após assessorar mais de vinte municípios na elaboração dos seus Plano
KERBAUY, 2016).

Nesse momento, será possível confrontarmos as propostas urbanísticas, as análises contidas nos planos diretores, com as projeções elaboradas pelos grupos de urbanistas, que, utilizaram, por sua vez, de Congressos ${ }^{5}$, de artigos publicados em revistas especializadas e da divulgação de projetos urbanos e/ou de arquitetura para difundir as suas concepções, que, no Brasil, de forma pioneira, foram definidas por Anhaia de Mello. Assim, será possível identificarmos o amplo processo de ressignificação de concepções teóricas-urbanísticas e a sua replicação no Brasil. Não pretendemos apenas elaborar um quadro descritivo das ideias, mas também, e, sobretudo, sistematizarmos as principais concepç̃es desdobradas de suas origens por diversos urbanistas que se consolidariam como pano de fundo dos Planos Diretores assessorados pelo vinte anos de atuação (1955-1972). Assim, será possível identificarmos as soluçoos dadas pelo urbanismo, baseadas na ideia de modelo (utopias) incorporadas em um ato de força à realidade das cidades.

Não objetivamos apresentar de forma pormenorizada cada experiência de desenvolvimento dos Planos Diretores dos municípios assessorados pelo Centro, mas sim detalhar o solo filosófico utilizado por urbanistas da FAU na elaboração da proposta de política urbana para as cidades brasileiras.

\section{A CORRENTE URBANíSTICA PROGRESSISTA}

TONY GARNIER (1869-1948)

Francês de Lyon era discípulo de Paul Blondel e dedicou parte de sua vida à elaboração de um projeto, tido como o revolucionário em 1901, de uma cidade modelo. Entretanto, somente em 1917, escreve a obra, "Uma cidade industrial", que exercerá considerável influência em um conjunto de urbanistas progressistas. Ao se partir do princípio de que a Carta de Atenas ${ }^{6}$ seja um importante marco do urbanismo progressista, "Uma cidade industrial" poderia ser considerada o primeiro manifesto dessa corrente, anterior à consolidação da Carta. A proposta contida em "Uma cidade industrial" pode ser dimensionada como um marco, fundamentalmente, por instituir um conjunto de princípios diretores à análise e à separação das funções urbanas, ao destaque dado aos espaços verdes (que cumpririam a função de elementos isoladores) e a utilização sistemática de elementos novos aos projetos arquitetônicos das construções, como o concreto armado.

Os desenhos de Garnier são mais audaciosos que suas construções; há uma referência constante à antiguidade, principalmente, em seus projetos residenciais, que utilizam o átrio ${ }^{7}$ como um de seus componentes. A obra de Garnier, focada por Choay (2013), assume posição de destaque, pelo fato de ter sido por meio dela que o autor pôde exercer um papel de protagonista no processo criativo da arquitetura moderna. Para este, as novas cidades deveriam ser fundadas sob a égide da economia industrial com características rigidamente pré-estabelecidas, no momento de sua concepção, tais como:

- Porte médio, do ponto de vista populacional, até 35 mil habitantes,

- Estar próxima a centros produtores de matérias-primas, ou seja, a um mercado de trabalho suscetível de ser utilizado;

- Estar inserida em uma rede de circulação que facilitasse o transporte de insumos (destinados às indústrias) e ao escoamento de mercadorias.

O aspecto setorizado de sua concepção de cidade é perceptível, quando Garnier trata dos elementos considerados nucleares por ele, tais como: fábrica, cidade e estabelecimentos hospitalares. O pensador reforça a opção pela setorização, pelo zoneamento por fruição, em uma cidade como sendo o fio condutor para o estabelecimento da ordem ao caos (referimo-nos ao acelerado processo de urbanização das cidades industriais desprovido de ações de planejamento).

Essa opção, no entanto, guindou o autor a refletir e criar regulamentos sobre essas disposições setorizadas das funções em uma cidade: regulamentos de inspeção de limpeza e regulamentos sanitários, dentre outros. Da mesma forma, Garnier passou a categorizar outros espaços urbanos de acordo com o uso do solo ou fruição ${ }^{5}$ Os Congressos Internacionais da Arquitetura Moderna (do francês Congrès Internationaux d'Architecture Moderne ou simplesmente CIAM) tinham como proposta aglutinar e publicar as ideias da arquitetura e urbanística modernas no intuito de padronizar, mundialmente, seus ideais. No tinham como proposta aglutinar e publicar as ideias da arquitetura e urbanistica modernas no intu.
Anexo A, apresentamos quadro resumos dos vários Congressos do CIAM e os temas abordados.

'Documento produzido a bordo do navio Patris (navegando entre Marselha e Atenas) durante o IV CIAM no ano de 1933. Constitui-se em uma síntese das proposituras dos congressos anteriores em um texto dogmático e polêmico que orientava, estabelecendo critérios, a organização das cidades. Tornou-se público só em 1941, por iniciativa de Le Corbusier que escreve sua versão final, orientando o texto de acordo com suas convicções. O termo átrio surge na arquitetura grega e romana para designar o pátio central da casa. Na atualidade, também designa uma sala espaçosa de um hotel ou edifício público, que dá acesso a outra área de mais importância.

\section{.}


para que esse determinado serviço passasse a ser ofertado ao cidadão na malha urbana.

Ao tratar do tema habitação, elabora orientações que irão desde a disposição de portas e janelas até os tipos de materiais que deveriam ser utilizados. Esse conjunto de regras impostas para a habitação serão incorporadas ao que, no Brasil, denominamos Código de Obras, presente, via de regra, em todos os municípios. Esses códigos, assim como as orientações de Garnier, instituem a regulamentação do parcelamento do solo urbano, no que diz respeito à metragem mínima do lote (geralmente $150 \mathrm{~m}^{2}$ ) e à taxa de ocupação do lote ou area construída (geralmente, inferior à metade da superfície total, sendo que o restante do lote não poder ser impermeabilizado). Além desses aspectos normativos, que confirmariam, na concepcão de Garnier, uma racionalidade no desenvolvimento urbano, preocupa-o a própria disposição dos lotes nos bairros, de maneir que deixassem uma passagem livre (desimpedida de barreiras físicas como cercas e muros) e que permitissem atravessar a cidade, em qualquer sentido, sem a necessidade de transitar pelas ruas. A baixa taxa de ocupação do lote, somada à exigência de não impermeabilização do terreno, conferiria ao solo da cidade, como um todo, $\mathrm{o}$ aspecto de um grande parque, sem nenhum muro divisório que limitasse as unidades habitacionais.

A planta geral da cidade proposta compreenderia, ainda, uma rede articulada de ruas paralelas e perpendiculares. A via arterial mais importante partiria da estação de estrada de ferro (de leste para oeste). As demais ruas, no eixo norte-sul, teriam 20 metros de largura e seriam arborizadas em ambos os lados; as ruas, no eixo oeste-leste, teriam 13 ou 19 metros de largura, sendo que as de 19 metros seriam arborizadas somente do seu lado Sul (conforme podemos notar na Figura 1 Tony Garnier - A cidade industrial, canto superior e esquerdo)

Os estabelecimentos públicos foram alocados, na proposta de Garnier, à área central e distribuídos em 3 grupos. O primeiro grupo deveria ser ocupado pelas salas de assembleia, destinadas às sessões do parlamento, apresentações culturais ou grandes reuniões com capacidade de receber um público de 3000 pessoas; uma segunda sala para 1000 ouvintes, organizada em bancadas e mais duas salas para 500 pessoas cada, para realização de conferências, projeções, etc. Na sua concepção de cidade e configuração de espaços públicos, os sindicatos, as sociedades e grupos diversos contariam com uma grande quantidade de pequenas salas de reunião e desenvolvimento de suas atividades.

Quanto aos serviços administrativos, Garnier projetou os edifícios e ambientes urbanos numa sequência narrativa - como pudemos notar -, ou seja, um modelo urbano possível de utilização e com potencial de afrontamento dos sistemas político-administrativos, técnicos, sociais, jurídicos e econômicos estabelecidos, evidenciando um novo formato de urbanização para o século XX.

Essa característica fica evidente na sua proposta para a localização dos principais estabelecimentos públicos no centro da aglomeração, basicamente compostos por três grupos: a) serviços administrativos e salas; b) coleções, tais como documentos históricos e demais tipos que interessassem à cidade, do ponto de vista arqueológico, artístico, industrial ou comercial; c) estabelecimentos desportivos e de espetáculos.

As escolas deveriam ser espalhadas pelos bairros e deveriam atender a crianças até 14 anos. Na outra extremidade da cidade, a nordeste, estariam localizadas as escolas secundárias. A formação dos alunos deveria atender às necessidades industriais da cidade, ou seja, um tipo de ensino especial para um número restrito de alunos que se dedicariam à administração e ao comércio e, para um maior número, de um ensino profissional-industrial. Garnier também detalhará os estabelecimentos voltados para a saúde pública, num total de 715 leitos, ao norte da cidade e contornados por canteiros verdes. À região da estação férrea seriam reservadas, fundamentalmente, as habitações comunitárias, tais como: hotéis, grandes lojas de departamentos, limitando a essa região as construções verticalizadas. A estação, considerada de importância média, estaria nas cercanias das grandes avenidas, que a conectariam à cidade velha e contaria com serviços públicos ao nível de ruas. Suas linhas férreas ficariam no subsolo, dando acesso aos usuários às plataformas e a espaços destinados à espera das composições pelos cidadãos. Segundo a concepção do autor, o prédio da estação, composto por uma visível torre de relógios, seria o marco principal da cidade, de modo que o possível processo de verticalização não comprometesse a sua visualização. $\mathrm{O}$ transporte ferroviário intermunicipal dar-se-ia por trens de alta veloci dade, daí a necessidade, segundo o autor, de seu percurso ser completamente em linha reta.

A administração pública municipal gerenciaria certos estabelecimentos considerados especiais, tais como: os matadouros, o serviço de águas, os armazéns de produtos farmacêuticos e lácteos. Os resíduos também deveriam ficar a cargo da administração, assim como o fornecimento de água e energia elétrica.

A principal atividade econômica desse modelo de cidade industrial seria impulsionada por uma metalúr gica. Seus principais produtos seriam canos de ferro, chapas de ferro fundido, rodas, ferramentas e máquinas agrícolas. Dada à complexidade das funções (dos produtos produzidos pela metalúrgica), elas seriam compostas por altos-fornos, fundições de aço, oficinas de prensa, oficinas de montagem, doca para lançamento de navios, etc. O sistema de escoamento da produção seria composto por grandes avenidas arborizadas. No de navios, etc. O sistema de escoamento da produção seria composto por grandes avenidas arborizadas. No
entorno dessa aglomeração industrial, Garnier destinou áreas para as atividades agrícolas, criação de bichoentorno dessa aglomeração industrial,
da-seda, fiação, etc. (CHOAY, 2013)

Não é apenas a leitura do espaço urbano-industrial e as suas propostas identificáveis em outras metrópoles que colocam Garnier como um pioneiro do tipo de urbanismo progressista-moderno. Os materiais empregados em seus projetos também reforçam esse caráter despojado de suas propostas, tendo como referência o contexto no qual profissionalmente ele estava inserido. O cimento armado, por exemplo, incorporado à estrutura das construções, conferiria uma simplicidade na forma arquitetônica dos prédios. O emprego de tais materiais, argumenta, permitiria a configuração de grandes planos horizontais e verticais, que, por conseguinte, transfeririam para o ambiente urbano "... esse ar de calma e de equilíbrio que as harmoniza [refere-se às linhas arquitetônicas das construç̃es verticais e/ou horizontais] com as linhas da natureza...” (GARNIER apud CHOAY, 2013, p. 170).

\section{GEORGES BENOIT-LÉVY (1880-1971)}

O segundo nome importante, dentro da corrente urbanística progressista, será Georges Benoit-Lévy, nascido em 1880 na França. Sua proposta conecta-se ao grupo que Tony Garnier fazia parte e que produziu o denominado movimento das cidades operárias, que, por sua vez, estimulou mais tarde a organização da Associação Francesa das Cidades-Jardim. A sua obra de maior relevo foi "A Cidade-Jardim", inspirada na leitura dos escritos de Ebenezer Howard, que, por um período de estudos na Grã-Bretanha, teve contato direto com algumas cidades-[pilotos]-jardins ingleses. No entanto, destaca Choay (2013), a concepção inglesa de cidade-jardim foi ressignificada na França de uma maneira distorcida, pois reforçava aspectos paternalistas, sem dialogar, destarte, com o espírito culturalista e com a visão comunitária, originais na concepção de Ebenezer Howard. $\mathrm{O}$ seus principais argumentos referem-se às dimensões da arborização e higienização da malha urbana para que, no limite, a reprodução da força de trabalho (operários) atingisse patamares mais elevados.

Na sua concepção, seria em torno das fábricas que deveriam ser criados os centros de vida social e, por conseguinte, caberiam aos industriais criar novas cidades, sadias e belas. Nesse sentido, quando a situação econômica é próspera, as condições sociais e a moral também seriam melhoradas. Subtraímos destas orientações, contidas no pensamento de Benoit-Lévy, o pano de fundo de um debate acalorado sobre as relações sociais e de produção capitalistas, atuando como fios condutores para o alcance da cidadania e da justiça social. E, ao tecer essa relação causal - a industrialização conduziria à cidadania e à justiça social -, o autor negligencia todo um debate em voga, já no final do século XIX, de que desenvolvimento econômico não produziria espontaneamente distribuição de renda e oportunidades.

A cidade industrial deve ser a cidade nova, que romperia com os anacronismos medievais e barrocos, pois a indústria, em sua concepção, desenvolver-se-ia sem interrupção. E, para que essa harmonia social fosse alcançada, bastaria, segundo Benoit-Lévy, responder às seguintes questões: "Como trabalhar na indústria de um modo sadio e como viver perto da fábrica de um modo sadio?”. Benoit-Lévy marginaliza, portanto, muitas umformações sistematizadas a partir de dados consistentes, compilados por pensadores críticos desse modo de produção capitalista ao longo das décadas, principalmente, a partir do último quartel do século XIX, tais como: violência urbana, condições de trabalho dos proletários industriais, fragilidade ou ausência de arcabouço jurídico que garantisse direitos à classe operária, marginalização espacial dos proletários de quaisquer condições de sobrevivência, restrições de acesso ao solo urbanizado e/ou a unidades habitacionais dignas.

Benoit-Lévy, ao fundamentar seu pensamento em defesa do modelo de cidade da e para a indústria, revelanos certa ingenuidade ou um cego comprometimento com o processo de mercantilização do espaço urbano. Fica evidente a miopia interpretativa e reflexiva de Benoit-Lévy, ao analisar a sociedade e sua época com nítidas tendências - do ponto de vista e econômico produtivo-, em formar corporações transnacionais em um circuito cada vez mais mundializado de produção.

As operações de uma economia capitalista jamais são suaves e o chamado "ciclo" do comércio, que compreende oscilações, que vão do extremo aquecimento ao resfriamento das relações comerciais, já era de conhecimento de muitos intérpretes ou observadores econômicos. A própria história da economia mundial, desde 
a Revolução Industrial inglesa, demonstra que o progresso técnico, de variável crescimento econômico e crescente globalização, promoveu uma divisão internacional e complexa do trabalho. Configuraram-se, já nas primeiras décadas do século XX, uma rede intensa de fluxos e intercâmbios de capitais que conectam todas as partes da economia mundial ao "sistema global" (Hobsbawn, 1995, p. 92). De qualquer forma, caso BenoitLévy estivesse se referindo, especificamente, ao período entre guerras, seria possível identificar uma certa estagnação econômica, principalmente, no que diz respeito ao fluxo de imigrantes às economias capitalistas centrais, como Inglaterra e EUA, que poderiam gerar uma nova tendência no desenvolvimento urbano de cidades industriais. Em outras palavras, o cenário de incertezas que abalava os homens de negócios e os Estados, estimularia um comportamento protecionista, no intuito de blindar suas economias de ameaças externas, ou seja, os riscos que compõem o campo de ação dos industriários seriam fatores limitantes às atitudes ousadas de outrora, no que diz respeito ao investimento em novos processos produtivos ou novas plantas industriais.

Benoit-Lévy capta o momento no qual está inserido e consegue, até certo ponto, dimensionar algumas dificuldades enfrentadas pelo capital para se desenvolver nas cidades. Dito de outra forma, preconiza, em sua proposta, uma variável importante que dificulta a difusão de cidades-industriais jardins pela França: a escassez de terreno a baixo preço e perto de estruturas viárias voltadas para comunicação/escoamento da produção, de força motriz rendosa e “... com mão-de-obra econômica” (BENOIT-LÉVY apud CHOAY, 2013, p. 172).

Diante desse cenário e pertencente a um contexto, que sabemos ser mais amplo de crise do sistema capitalista mundial dos primórdios do século XX, Benoit-Lévy sugere que a Associação das Cidades-Jardins - que propunha um tipo de cidade-jardim à francesa - intermediasse o processo de organização do trabalho e da "... higiene social junto aos industriais para [...] dar-lhes todas as informações que possam desejar no que diz respeito à instalação de suas fábricas e à higiene de suas aglomerações operárias" (BENOIT-LÉVY apud CHOAY, 2013, p. 172). Em moldes semelhantes, como afirmamos anteriormente, Anhaia Mello imputará à Universidade de São Paulo, mais especificamente a um instituto de pesquisas, o CEPEU, o papel difusor de concepções urbanísticas que moldarão instrumentos, como Planos Diretores, no intuito de sanear os espaços urbanos desprovidos de regulamentação de uso e ocupação. A Associação francesa forneceria, portanto, informações em matéria de organização do trabalho e da higiene pessoal para que, posteriormente, fosse possível a instalação de fábricas em "cidadezinhas industriais modelo". Incutida na proposta de formação de cidadezinhas industrial está a concepção de distribuir no território indústrias que se agrupariam em determinadas regiões. É o que mais tarde será utilizado por Anhaia Mello, conceitualmente, para propor o que denominou "Federação de Pequenas Cidades" e promover ações em dois eixos: desconcentrar a produção industrial do eixo Rio-São Paulo - como alternativa para a diminuição do fluxo migratório que essas atividades atraíam - e homogeneizar o desenvolvimento econômico - por demais concentrado no referido eixo e já com nítidos problemas sociais e ambientais que se refletiam na qualidade de vida urbana dos grandes centros. E, nesse sentido, encontramos uma relação entre a proposta de Benoit-Lévy com a de Anhaia Mello, o que configura um primeiro campo de ressignificação conceitual, que dará suporte a um debate que penetrará no âmbito político ou de uma reforma político-administrativa da relação entre os entes federados no Brasil, que discutiremos mais adiante.

As cidades industriais de Benoit-Lévy constituíram-se, pouco a pouco, em subdivisões políticas que agrupariam setores econômicos regionalizados, ou seja, uma proposta de planejamento territorial regional também presente no pensamento de Anhaia Mello

Para Benoit-Lévy, o cenário econômico, vivido pela Europa do início do século XX, prescindia de ações para remediar a crise que o setor industrial enfrentava. Sua proposta de cidade-industrial tinha por objetivo organizar o trabalho industrial e agrícola, para que os empresários alavancassem lucros certos e que proporcionasse aos operários meios de viver em condições normais e que garantiriam a todos os habitantes o bem-estar, a segurança e a saúde. No entanto, para que esse objetivo se efetivasse, os terrenos urbanos deveriam reunir sua tripla condição: "ser baratos, estar próximos a vias de comunicação e oferecer facilidades necessárias à exploração agrícola e industrial”. (BENOIT-LÉVY apud CHOAY, 2013, p. 173).

\section{WALTER GROPIUS (1883-1969)}

Um terceiro integrante do grupo de urbanistas progressistas, que exerceu sobre a arquitetura e o urbanismo contemporâneo um impacto ideológico similar à de Le Corbusier (nos anos 1920-1930), foi o alemão Walter Gropius.
Gropius foi essencialmente um catedrático da reconhecida escola de Baubaws e que, posteriormente, desempenhou suas atividades na Faculdade de Arquitetura de Harvard, pois Baubaws havia sido fechada por ordem do governo nazista, em 1933, marcando efetivamente duas gerações de urbanistas. Sua formação, como profissional e pesquisador-professor, foi inspirada em P. Behrens, um arquiteto alemão que tendeu a articular profissional e pesquisador-professor, foi inspirada em P. Behrens, um arquiteto alemão que tendeu a articular
o conhecimento e a prática arquitetônica às necessidades do desenvolvimento industrial. Gropius pertence a o conhecimento e a prática arquitetônica às necessidades do desenvolvimento industrial. Gropius pertence a
um grupo maior, composto por Mies Van de Rohe, Le Corbusier, Oud e Mendelson, que fundou a arquitetura racionalista, um tipo de arquitetura que recorria constantemente ao aço, vidros e formas geométricas despojadas nos projetos de prédios.

No tocante à concepcão urbanística, os termos principais difundidos por Gropius giravam em torno de conceitos de padronização, de pré-fabricação e da criação de um espaço que dialogasse com o movimento progressista que a arquitetura vivia naquelas décadas iniciais do século XX. Esses pressupostos foram aplicados em duas cidades operárias planejadas por este, Dammerstock de Karlsruhes (1927-1928) e o Siemensstadt de Berlim (1928) ${ }^{8}$. Essas cidades/bairros serão o modelo do urbanismo progressista e servirão de inspiração para outras intervenções, que gerariam estudos de alojamentos em série, no tipo de habitação denominada de casa-pré-fabricada, principalmente nos EUA.

O ano de 1934 impôs profundas mudanças na trajetória acadêmico-profissional de Gropius, pois, ao fugir do nazismo, refugiou-se na Grã-Bretanha, onde se dedicou à elaboração de projetos voltados para a arquitetura escolar. Três anos depois, em 1937, mudou-se para os Estados Unidos, sendo nomeado diretor da Faculdade de Arquitetura de Harvard, mas não se ateve apenas às atividades acadêmicas, pois, no mesmo ano, fundou a agência de arquitetura, The Architect's Collaborative, que difundiu internacionalmente o estilo arquitetônico americano. Vejamos algumas análises que Gropius elaborou sobre a questão urbana-industrial, durante sua atuação junto à Faculdade de Arquitetura de Harvard, pautadas, fundamentalmente, nos conceitos de organização, essência, função e uniformização que a indústria necessitava para servir-se do espaço urbano.

Inicialmente, Gropius focaliza as mudanças no campo da construção civil que, em resumo, estariam a gerar certo espírito novo em todos os países, por ele classificados, civilizados. As mudanças também revelariam um novo espírito de organização para conceber um móvel ou uma casa, que the proporcionaria funcionalidade. A essência de uma construção localizar-se-ia na fronteira comum às diversas áreas de conhecimento acionadas pelo profissional-arquiteto na concepção de um projeto, tais como a mecânica, a estatística, a óptica, a acústica e aos padrões de proporcionalidade das formas, que, para Gropius, pertenceriam ao "reio do espírito" e, por assim ser, subordinariam o material e a construção em si.

Para Gropius, o exercício profissional da arquitetura é individual, mas está inserido em uma dimensão - a humanidade ocidental-industrial - que lhe confere um espírito do seu espaço-tempo e aos materiais inovadores (produzidos pela indústria e economia modernas) que lhe imprimem exatidão, rigor formal e simplicidade dentro da diversidade.

Ao analisar a cidade como um todo, Gropius parte de observações sobre a rua - tida como uma unidade superior - para, depois, focar as células que compõem um segundo grupo-tipo de caráter econômico ou residencial. A concepção de cidade-standart está relacionada a intervenções processadas em meio urbano e que promovam uma hegemonia, que, para este, é a "marca própria de uma cultura urbana superior" (GROPIUS apud CHOAY, 2013, p. 177).

A concepção de Gropius sobre a cidade passa pela regulamentação dos tipos-padrões de edifícios do ponto de vista dos materiais utilizados na sua construção e, evidentemente, na orientação normativa do gabarito desses edifícios. Ações que, do seu ponto de vista, confeririam latitude e organização ao desenvolvimento urbano. Essa é, também, a constante referência a que fará Anhaia Mello com o fito de estimular, no urbanismo paulistano, novas bases normativas e econômicas. Os estudos elaborados, este último em o "Código de ocupação listano, novas bases normativas e econômicas. Os estudos elaborados, este último em o "Código de ocupação
lícita do solo", do ano de 1956, apontam para a necessidade de se criar parâmetros normativos que pudessem frear o desenvolvimento acelerado e "desorientado" da conurbe paulistana, que se expandia a golpes de empreendimentos urbanísticos privados que geravam novos bairros. (TOLEDO, 2013).

A cidade industrial, que produzia como um de seus produtos a segregação espacial de classe operárias, era uma preocupação constante de Gropius. E é da concepção, que Gropius tinha do arquiteto como coordenador, voltado para a mitigação, ao mesmo tempo, dos problemas plásticos, técnicos, sociais e econômicos, origiBairro residencial operário que levou esse nome, dado a sua proximidade com a fábrica Siemens e que, portanto, atenderia principalmente seus rabalhadores. 
nários das intervenções da construção civil em uma cidade, que o levou ao estudo do urbanismo pelo viés funcionalista - a partir da rua -, traçando diretrizes e fórmulas que pudessem conferir à cidade caracteristicas de um organismo funcional, na qual as demandas dos homens deveriam ser claramente contempladas. Nesse momento, ele apresenta suas escolhas arquitetônico-urbanísticas na organização dos centros urbanos. Quanto ao tipo ideal de construção, aponta que o mais adequado seria justamente a mescla de formas de habitar horizontalizadas com jardins e verticalizadas, ou seja, os prédios de apartamentos de oito a doze andares satisfariam todas as exigências em matéria de ar, luz e de segurança. Essa forma de habitação possuía, ainda, a vantagem de dispor as unidades habitacionais com janelas que se abririam para o céu e o espaço verde que separava os blocos, também destinados como áreas de lazer para as crianças brincarem. Os tetos - terraços uma preocupação estético-arquitetônica constante - poderiam ser ocupados por jardins, contribuindo ainda mais para a elevação da qualidade paisagística e ambiental das cidades, na concepção de Gropius.

Portanto, o urbanista defende a verticalização dos centros urbanos que se mesclaria às construções horizontais. Importante destacar, entretanto, que as zonas urbanas residenciais de baixa densidade demográfica teriam, predominantemente, construções horizontais, ao passo que, os centros muito populosos seriam ocupados po prédios de oito a doze andares. Essa é a solução que apresenta o autor, quando reflete sobre a necessidade premente dos grandes centros urbanos em reduzir o tempo de deslocamento entre os diferentes centros de negócios de uma cidade.

Gropius apresenta, ainda, um conjunto de vantagens, que residiriam na escolha de imóveis altos, divididas por nós em três pontos centrais: 1) Imóveis de dez andares apresentam $60 \%$ da superfície útil de uma cidade comum - elevado aproveitamento da mesma quantidade de ar e luz; 2) O custo final dos imóveis de dez andares proporciona uma economia de até $40 \%$ em comparação aos imóveis de dois andares; 3) Os intervalos maiores entre os imóveis de dez andares permitem um ganho considerável em quantidade de luz, de ar e de sol.

Entretanto, o autor alerta que o processo de verticalização, como o que ocorreu na cidade de Nova York, poderá não privilegiar condomínios habitacionais, mas arranha-céus voltados para a especulação imobiliária. Esse problema poderia ser resolvido, controlando-se a densidade da construção das regiões centrais de uma cidade, tendo como parâmetro a infraestrutura urbana voltada para a rede de transporte, ou seja, para a mobilidade.

Nesse sentido, argumenta o urbanista, o intenso processo de industrialização elevou consideravelmente os índices de urbanização da sociedade, estabeleceu uma relação causa-efeito entre fluxos migratórios campo-cidade e a congestão dos centros urbanos. Há, portanto, nos países da economia capitalista central, uma demanda por reconstruir o modelo de cidades que passariam a ser mais espaçosas e entrecortadas por espaços verdes. Isso só será possível a partir de investimentos em um sistema de transportes que se relacione ao ciclo de desenvolvimento urbano imposto pela economia industrial.

O crescimento das cidades industriais era um dado certo e irreversível, na concepção de Gropius. Por esse motivo, imaginava um futuro em que regiões inteiras estariam tomadas por cidades com unidades condominiais menores, formando uma rede de municípios dispersos e espaçosos (cidades verdes disseminadas em um campo urbanizado). Esse formato futuro cumpriria uma missão histórica: a reconciliação entre o campo e a cidade, pois, ao assumirem esse formato, comunidades e regiões planejadas desanuviariam as antigas cidades que se expandiram, pautadas pela força do capital especulativo - os bairros ressurgiram como locais orgânicos, comerciais e culturais.

A "descongestão" das cidades, temática constante nos debates entre os urbanístas-planejadores dessas primeiras décadas do século XX, será, portanto, o produto de um processo continuado de redistribuição populacional em novas unidades urbanas difundidas em um território. Essa distribuição desconcentraria a capacidade produtiva-industrial, aglutinada em imensas cidades industriais. Portanto, o planejamento regional, fundamentado nas bases teóricas de Gropius, asseguraria a recuperação, não apenas de espaços urbanos consolidados e congestionados, mas, sobretudo, reestabeleceria a capacidade produtiva e de consumo de indivíduos distribuídos em cidades-industriais de menores portes.

Anhaia Mello entendia ser necessário um novo pacto federativo em que o município pudesse ser aquinhoado com recursos proporcionais às soluções necessárias para os seus desafios urbanos, oriundos desse processo de concentração industrial, expansão urbana e crescimento demográfico. Em 1951, encaminhou proposta de reforma constitucional que pressupunha repasses federais aos municípios, equilibrados com suas responsabilidades. (TOLEDO, 2013).

$\mathrm{Na}$ esfera estadual, a sua proposta, denominada "O Plano Regional de São Paulo", recorria à tese da limitação do crescimento (fruto do acelerado ciclo de desenvolvimento industrial da cidade de São Paulo) para conter a exploração imobiliária e proporcionar equilíbrio no desenvolvimento regional brasileiro. O Plano ainda propunha a elaboração de um Plano Estadual, a obrigatoriedade de organização de planos para os municípios, a partir de um determinado nível populacional, e a criação de um Conselho Estadual de Urbanismo (CEU). Com relação aos problemas com os municípios industrializados, propunha-se a criação de uma comissão do Plano da Região Industrial de São Paulo (COPRIsp), que, dentre suas atribuições, podemos destacar: proibir novas indústrias na cidade de São Paulo e estimular a dispersão destas para outros municípios. Há, portanto, um tangenciamento das propostas elaboradas por Anhaia Mello com as pensadas por Gropius. A nova unidade urbana, vislumbrada por ambos, era aquela em que o ponto de partida fosse a reconstrução das velhas grandes cidades e o controle habitacional das novas em torno de cinco a oito mil trabalhadores. A palavra de ordem adotada por eles é a "desconcentração industrial" dos grandes centros para uma base urbano-territorial regional.

Identificamos em Gropius uma das referências utilizadas por Anhaia Mello ao dedicar-se à problemática urbana da capital de São Paulo. Ao propor a limitação forçada do crescimento da cidade de São Paulo, vinculada à ideia regionalista de desenvolvimento e à polinucleação, estabelece um diálogo muito próximo ao que ocorria na Europa e nos Estado Unidos da América do Norte, qual seja, a necessidade de dispersar o desenvolvimento da indústria, aglutinado em grandes centros urbanos, como uma alternativa para solucionar o problema social, urbano, ambiental e de sobrecarga da infraestrutura urbana das capitais-industriais.

A proximidade de Gropius não se dava apenas na dimensão das ideias, mas também por meio da participação em eventos realizados no Brasil, como na $1^{\text {a }}$ Bienal de São Paulo, em 1951, e que serviram de ponte na criação de uma identificação, por exemplo, do IAB/SP com as artes plásticas de vanguarda e com a proposta progressista (moderna) de arquitetura.

A questão social era um problema enfrentado pelas administrações municipais, desde as primeiras décadas do século XX. A Primeira Guerra Mundial (1914-1918) pressionou a subida dos índices inflacionários e a escassez de alimento tornou mais aguda o cenário. Os operários buscaram guarida no sindicalismo - uma arena de lutas para consolidar direitos trabalhistas -, provocando muitas greves gerais, em 1917 e 1918, na cidade de São Paulo. Contudo, as dificuldades sentidas pelos operários, principalmente no que concerne à alta dos preços dos produtos alimentícios, por conta do recrudescimento da inflação, também estavam presentes no cotidiano da classe média urbana. Por esse motivo, entre 1910 e 1918, as campanhas civilistas ${ }^{9}$,em São Paulo, incluíram demandas dos trabalhadores operários. A aderência da classe média paulista ao Partido Republicano e o reconhecimento de que os operários e suas organizações deveriam ter suas demandas contempladas, culminou na promulgação do Código Sanitário Estadual (1916), que incluía normativos sobre o emprego de menores. Na prática, exigia que os menores de dezoito anos tirassem licenças de trabalho que atestassem a idade, o consentimento dos pais e a comprovação de que eram alfabetizados (DEAN, 1991).

Charles-Edouard JeAnNerRT - Le Corbusier (1887-1965)

Entretanto, do ponto de vista do nosso escopo de pesquisa, no período de análise do século XX a que nos dedicamos, cabe-nos a tarefa de dar relevo à obra urbanística de Charles-Édouard Jeannerrt, chamado de Le Corbusier, como último representante da escola que, aqui, denominamos de "progressista" e que, também, corbusier, como último

cativara Anhaia Mello.

Le Corbusier ocupa lugar de destaque no movimento moderno, sendo que sua influência deriva da obra realizada e, sobretudo, da enorme atividade desenvolvida, assim como pelos conceitos e ideias que disseminou. Dimensionava o campo da arquitetura e do urbanismo como indissociáveis na prática de novas técnicas de construção, somadas a uma nova visão do espaço, que originaram a denominada cidade moderna.

A proposta de cidade de Le Corbusier engloba temas, como classificação das funções urbanas, multiplicação dos espaços verdes, criação de protótipos funcionais e racionalização do habitat coletivo (CHOAY, 2013). O percurso de Le Corbusier inicia-se, em 1922, com o Plano de Cidade Contemporânea que abrigaria três milhões de habitantes. Sua proposta contemplava:

"A campanha civilista foi uma campanha eleitoral para a Presidência da República na primeira década do século XX. O nome "civiista" foi cunhado pelo então candidato a presidência Rui Barbosa, que tinha como vice de chapa Albuquerque Lins (Presidente do Estado de São Paulo), em oposição à candidatura do Marechal Hermes da Fonseca, apoiado pelo Presidente Nilo Peçanha. 
[..] centro de uma grande cidade com edifícios públicos, escritórios e habitações. Apresentava então três modelos tipológicos e construtivos de novos edifícios: a grande construção de escritórios, a habitação em redents (denteada) e a habitação em immeubles villas (edifícios-palácios) com jardins suspensos. (LAMAS, 2014, p.351)

A cidade, como um todo, não foi contemplada nesse projeto, pois se dedicou, com riqueza de detalhes, ao centro da metrópole, com 600.000 habitantes, envolvido por uma faixa verde que indicaria a localização de cidades-jardim, destinadas ao alojamento da maior parte da população. No entanto, vale destacar que Le Corbusier projeta seus esforços em expor uma visão arquitetônica da cidade, considerando o organismo urbano, a partir de uma concepção de funcionalidade, centrada no desenho dos edifícios e a sua região imediata.

Três anos mais tarde (1925), após apresentar o projeto da Cidade Contemporânea (1922), Le Corbusier apresenta o Plan Voisi, como uma proposta que serviria para indicar o caminho crítico e metodológico para intervenções sobre uma zona de Paris. O Plan Voisin propunha devastar a malha urbana parisiense, apenas conservando prédios históricos que ficariam envoltos por zonas verdes. No terreno libertado, Le Corbusie propunha a construção de vários edifícios idênticos, com 200 metros de altura, impactando uma grande parte da região central de Paris, destinada à habitação e escritórios.

Em 1930, Le Corbusier volta em cena com mais um projeto conceitual polêmico, denominado Ville Radiense (Cidade Radiosa), apresentado no II Congresso CIAM $^{10}$, em Bruxelas, em que é possível subtrairmos os seus princípios doutrinários sobre o pensamento urbano: Uma cidade verde com elevado percentual de solo livre; Construções monumentais assentadas em pilotis que liberavam vãos livres sob os prédios; Edifício configurados em função do eixo helioférmico para um melhor aproveitamento da luz do dia; Unidades habitacionais com a presença de equipamentos urbanos elementares.

Ao longo dos anos, Le Corbusier revisitará esses princípios e elaborará propostas para criação de conjuntos de unidades habitacionais em prédios que comportariam cerca de 1.800 habitantes, integrados com equipamentos urbanos necessários para o atendimento das necessidades básicas dos cidadãos, como creche, escola pré-primária e rua comercial

E notória a atenção dada por Le Corbusier à unidade habitacional no conjunto de seus escritos, debates e projetos. Ele se opõe efetivamente à cidade tradicional, assentada no quarteirão e no plano marginal, ao propor diferentes modelos urbanos. Destarte, valoriza as grandes construções habitacionais (prédios de 200 metros de altura para alojar 1.800 pessoas) em detrimento do quarteirão. A sua proposta de organização da zona residencial será o contraponto da unidade de vizinhança.

A ideia de unidade de vizinhança origina-se de um debate promovido por sociólogos americanos ${ }^{11}$, no início do século XX, ao constatarem que as relações sociais entre vizinhos, frequentes nos antigos bairros, tendiam a se extinguir nos novos formatos de ocupação do espaço urbano em grandes metrópoles. O movimento urbanístico capta esse fenômeno identificado na Sociologia (urbana) e, com a unidade de vizinhança, preconizava recriar os laços societários por meio da planificação urbana. A ideia central do conceito seria a criação de unidades habitacionais (bairros), controladas do ponto de vista populacional e de extensão territorial, possuindo, ainda, equipamentos e serviços alocados, de tal forma, que os cidadãos pudessem estabelecer, naturalmente, relações sociais com base em uma vida comunitária.

Clarence Artur Perry, nos anos 1920, em seus estudos sobre as relações entre habitantes e equipamentos urbanos, apresenta contribuições importantes na consolidação do conceito unidade de vizinhança. O centro da proposta elaborada por Perry está na ordenação dos equipamentos urbanos (sociais) nas proximidades dos núcleos habitacionais. As vias utilizadas pelos automóveis não deveriam interferir nos acessos aos serviços e conturbar o ambiente em que se desenvolve a vida comunitária

${ }^{10} \mathrm{Em} 1928$, a Sociedade das Nações lança edital para concurso de propostas urbanísticas que seriam apresentadas na exposição de Arquitetura en Stuttgart, Alemanha, em 1929. A proposta do concurso era verificar as semelhancas de métodos e objetivos com que muitos arquitetos trabalharam em diversos países. Portanto, propunha-se aglutinar essa identidade (identificada a partir das semelhanças de métodos) em uma associação profissional que nasce um ano antes da exposiçãao de Stuttgart, no castelo La Sarrar, com a primeira reunião de arquitetos modernistas. Assim, forman os CIAM's, que totalizaram 11 congressos durante 30 anos.

"Em Lamas (2014), encontramos referências a um conjunto de sociólogos americanos e suas respectivas obras, que teorizam sobre a unidade de vizinhança: Park, Robert; E. Burgess; Ernest, W. The City. The University of Chicago, 1925; Cooley, Charles Horton. Social organization, 1913,
Woods, Robert A. The Neighborhood in Social Reconstruction, 1913.

Segundo o pressuposto de Perry, as relações sociais desenvolvem um padrão de sociabilidade comunitária a partir da utilização, pelos cidadãos, dos serviços comuns e necessários à vida cotidiana, tais como:

[...] desde a escola primária a lojas, terrenos de jogos e, em zonas mais ricas, a igreja, sala de reuniões e de teatro, clube e piscinas. Na unidade de 10.000 habitantes preconiza ainda um pequeno museu, teatro e de teatro, clube e piscinas. Na unidade de 10.000 habitantes
outros edifícios de utilização social. (LAMAS, 2014, p.317)

Paralelamente ao desenvolvimento da teoria da unidade de vizinhança, arquitetos e urbanistas, como Henry Wright e Clarence Stein, produziram intervenções urbanísticas em Nova York, em que replicaram princípios similares aos desenvolvidos por Perry. As propostas elaboradas para os conjuntos habitacionais, em Nova York, evidenciam o processo de capilarização dos conceitos teorizados pelos autores da unidade de vizinhança. A preocupação com a questão social e com a organização funcional da cidade: extensão e quantidades das unidades habitacionais, posicionamento e dispersão dos equipamentos e das rotas que serão trilhadas pelos cidadãos para acessá-los. A reconstrução das cidades europeias, do pós-Primeira guerra Mundial, também contribui para a disseminação da proposta no solo do Velho Mundo e, evidentemente, provocou um intenso debate sobre a questão habitacional e sobre os modelos organizativos das áreas residenciais na malha urbana.

A partir desses dois movimentos difusores da proposta da unidade de vizinhança (primeiramente em solo estadunidense e, depois, no europeu), urbanistas de vários países (independentemente da orientação político-ideológica) aderiram à proposta e passaram a utilizá-la constantemente em seus projetos pontuais e/ou planejamentos urbanos.

O conceito de unidades de vizinhança, como proposta para criação/organização de zonas residenciais, passou a ser adaptado a qualquer plano urbanístico. Em outros termos, universalizou-se no jargão urbanístico como remédio para os problemas enfrentados pelos grandes centro urbanos e como uma eficaz vacina para os demais centros, transformando-se no modelo de organização e desenho da área habitacional nas cidades.

Para Lamas (2014), duas grandes vertentes irão difundir a utilização da proposta de unidade de vizinhança. A Primeira vertente é identificável nas orientações que conduziram intervenções urbanísticas do conhecido "Plano da Grande Londres" (1944 - 1945) de Patrick Abercombrie. A unidade de vizinhança é o solo sobre qual se consolida todas as organizacões e planejamento da cidade. Na versão inglesa, a teoria da unidade de vizinhança mescla-se à concepção de cidade-jardim: bairros de baixa densidade, separados por vias arteriais, por zonas verdes e com os equipamentos urbanos no seu interior, semelhante à concepção original de Ebenezer Howard deste tipo de cidade.

A segunda vertente, que é permeável às realizações do nacionalismo europeu, terá como expoente máximo Le Corbusier, com a proposta de unité d'habitation, e suas reverberações junto a arquitetos urbanistas. Alguns de seus discípulos são Oscar Niemeyer e Lúcio Costa, com as super-quadras de Brasília. O modelo unidade de vizinhança, no seu processo de disseminação no Brasil, não ficou restrito ao Plano Piloto de Brasília. Lúcio Costa, difusor da proposta em solo nacional e discípulo de Le Corbusier, reconfigura a proposta de seu mentor e a incorpora no desenho urbano da área residencial da nova capital federal, Brasília. Essa vertente trabalha com a possibilidade de verticalização da proposta de cidade-jardim numa forma compósita com a teoria da unidade de vizinhança.

E notório, entretanto, o impacto que o conceito de unidade de vizinhança, capitaneada mundialmente por Le Corbusier, também se multiplica no solo filosófico urbanístico brasileiro em que se edificavam planos diretores em pequenos e grandes centros urbanos.

Em Araraquara, interior de São Paulo, no ano de 1962, iniciaram-se tratativas para a elaboração do seu Plano Diretor, a ser conduzido pelo urbanista e arquiteto, discípulo de Anhaia Mello, Gustavo Neves da Rocha Filho. Em 1963, Neves da Rocha, sob a guarida do CEPEU, remete memorial descritivo em que apontava a estrutura e os primeiros encaminhamentos do futuro instrumento de política urbana. Como um efeito em cadeia, Neves da Rocha reproduz a vertente urbanística racionalista de matriz europeia, ao afirmar que:

A ideia fundamental do Plano Diretor de Araraquara é a setorização. Cada setor constitui uma unidade de vizinhança cuja população máxima será da órdem (sic) de dez mil habitantes. Estes setores, em número de 22, tem a mesma função das super-quadras (sic) de Brasília, mas se constituem das quadras clássicas de 80x80 metros, existentes. Cada setor fica delimitado por vias principais de trânsito rápido, com largura 


\section{de 25 metros, duas pistas e canteiro central.}

$[\ldots]$

Todos os setores terão como centro, como coração, uma escola primária, um grupo escolar. As criança poderão alcança-lo (sic.) sem perigo de travessia de rua de movimento e caminhando sempre pela sombra de uma árvore amiga; a demilitação dos setores foi feita de tal maneira que para sua localização convede uma árvore amiga; a demilitação dos setores foi feita de tal maneira que para sua localização conve-
niente do grupo escolar nenhuma criança precisará, na situação mais desfavorável, caminhar mais de 600 niente do grupo escolar nenhuma criança precisara, na situação mais desfavoravel, caminhar
metros, isto é, mais de dez minutos." (ROCHA FILHO apud TOLEDO, 2013, p. 207-208).

Sobre o conceito de verticalização da cidade, mais uma vez, o parâmetro conceitual/teórico referenciado é o produzido por Le Corbusier. O memorial descritivo do Plano Diretor de Araraquara identifica:

Um setor de alta densidade, denominado $\mathrm{AD}$, misto comercial-residencial, juntamente com o setor $\mathrm{C}$, central, serão os únicos onde poderão surgir arranha-céus. É a parte velha da cidade e que embora hoje

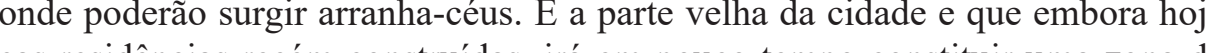
possua algumas magnificas residencias recém-construidas, irá em pouco tempo constituir uma zona de deterioração, isto é, uma zona em que os prédios residenciais vão mudar de uso, recebendo clínicas, escritórios, pensões e finalmente cortiços, até serem demolidos para dar lugar a prédios de escritórios ou de apartamentos. (ROCHA FILHO apud Toledo, 2013, p. 208).

O CEPEU atuou como o centro de pesquisa indutor do planejamento no estado de São Paulo e estará atrelado, de maneira detalhada e sistemática, às características dos Planos Diretores, que dialogam proximamente às vertentes metodológicas e conceituais aqui apresentadas.

Segundo Jacobs (2011), os planejadores da cidade-jardim projetaram conceitos de superquadras, bairro funcional, plano imutável, gramados entre áreas habitacionais, vias arteriais para veículos, zoneamento e redução do número de ruas, que, no limite, manteve o pedestre fora das avenidas e ruas. Segundo sua interpretação, esse tipo de urbanismo, que descentraliza funções, também isola, como num subúrbio, os cidadãos em imensos quarteirões ou em grandes unidades condominiais verticalizadas. Retomaremos, na secão 7 - O moderno $\mathrm{x}$ ortodoxo, a ofensiva aos princípios que moldaram o planejamento urbano e a reurbanização, a partir das críticas aos fundamentos do planejamento urbano, na perspectiva de Jane Jacobs, em Morte e Vida de grandes cidades (2011).

Subtraímos que, em ambas as vertentes, a unidade de vizinhança tem como solo conceitual a habitação que, agrupada em torno de equipamentos urbanos e serviços, constituiria uma nova plataforma de relação social voltada para a vida comunitária. A proximidade da perspectiva sociológica de interpretação dos problemas sociais (urbanos) alimentou nos planejadores e urbanistas a necessidade de criação de uma fórmula que, como mágica, constituiria comunidades de habitantes no seu bairro e, assim, resolveriam o problema de funcionamento das cidades.

O caminho trilhado pelo urbanismo "da unidade de vizinhança" colocava em segundo plano o desenho O caminho trilhado pelo urbanismo "da unidade de vizinhança" colocava em segundo plano o desenho
urbano e tiranizava a morfologia urbana ao funcionamento da cidade como um todo. As cidades têm a necessidade de uma diversidade de usos mais complexa e densa que, evidentemente, não poderá ser domesticada - se não à custa da segregação espacial da população em bairros (unidades de vizinhanças ou superquadras) -, que garante aos cidadãos uma sustentação mútua constante. As cidades criam em seu processo de desenvolvide trajetórias ou projetos pessoais dos cidadãos. O planejamento urbano, enquanto arte e ciência, deve captar, catalisar e nutrir as relações funcionais complexas e densas que propiciam a eclosão dos planos dos cidadãos. Portanto, afirma Jacobs (2011):

E tolice planejar a aparência de uma cidade sem saber que tipo de ordem inata e funcional ela possui. Encarar a aparência como objetivo primordial ou como preocupação central não leva a nada, a não ser problemas [..] Há um aspecto mais vil que a feiura ou a desordem patentes, que é a máscara ignóbil da pretensa ordem, estabelecida por meio do menosprezo ou da supressão da ordem verdadeira que luta para existir e ser entendida. (JACOBS, 2011, p. 14)

Podemos sistematizar em dois amplos aspectos os motivos do fracasso das unidades de vizinhança. Primei- ramente, pelo fato, abordado por Jacobs (2011), de as relações sociais nas cidades e, principalmente, mas não fundamentalmente, nos grandes centros, acontecerem em matrizes mais amplas e complexas e que não são contempladas por soluções aplicadas em um bairro ou superquadra. $\mathrm{O}$ próprio desenho urbano e a estrutura, contempladas por soluçoes aplicadas em um bairro ou superquadra. O proprio desenho urbano e a estrutura,
voltados para o transporte e as comunicações, ampliaram os horizontes das relações sociais que estão longe de ser localizados (rigidamente) em uma região da cidade. Conectado a esse aspecto, também podemos citar a não conformidade das formas urbanas (ou fórmulas urbanas unidades de vizinhança) ao dinamismo social e econômico, pelo qual poderá passar uma cidade ou, ainda, regiões de uma cidade no curso de sua história, tais como, necessidade de postos de trabalho no setor terciário, pequena indústria de bairro e manufaturas artesanais como alternativas para a ampliação da renda familiar.

O progressivo abandono da unidade de vizinhança inicia-se em 1960 e estende-se até os dias atuais. Todavia, alguns métodos de planejamento dos equipamentos, preconizados por esse conceito, a serem distribuídos na malha urbana, permaneceram vívidos. Ao abordarmos a próxima vertente urbanística, na seção 3.2, A corrente urbanística culturalista, notaremos claramente esse processo, pois o fenômeno de análise continuará o mesmo: a expansão industrial nas metrópoles.

\section{A corrente Urbanística Culturalista}

Cronologicamente, o modelo culturalista toma forma antes do modelo progressista e do próprio termo urbanismo. A Alemanha e a Áustria, dos anos 1880 e 1890, executaram algumas intervenções urbanas que dialogavam com essa vertente. Os países que se beneficiaram da onda urbanística-culturalista são aqueles que desenvolveram suas cidades a partir da segunda fase da Revolução Industrial (1850). O modelo culturalista não conta, na sua gênese, com representantes franceses. Destacamos, portanto, entre seus fundadores: Camillo Sitte, urbanista austríaco, que publica, em 1889, a obra Der Stadtebau, que obteve repercussão na Alemanha e Grã-Bretanha e Ebenezer Howard, jornalista inglês e estudioso das questões urbanas, que, sensibilizado com as condições sociais dos trabalhadores da grande Londres, elabora a obra Tomorrow (1898), considerada uma referência na essência do conceito da cidade-jardim. (HOWARD, 1996).

Como vimos, na seção anterior, o conceito de cidade-jardim será teorizado e tomará corpo em diversos formatos de intervenções urbanísticas mundo afora. Assumirá, portanto, importância basilar nas propostas urbanísticas que ganharão eco em diversos países e, segundo Jacobs (2011), influenciará diversas escolas que partirão de seus princípios ao conceberem projetos por décadas a fio. Por fim, abordaremos a atuação do arquiteto e urbanista Raymond Unwin, que será responsável, juntamente com B. Parker, pelo projeto e construção da primeira cidade-jardim (gardem-city) da Inglaterra, denominada Letchworth.

O conceito de cidade-jardim propõe uma nova morfologia de cidade que se forma no ambiente britânico do último quartel do século XIX. Para Howard, o princípio nuclear de sua proposta consistia em um diferente modelo de organização social, econômica e territorial em ambientes residenciais de baixa densidade habitacional com predominância de áreas verdes. Essas propostas de cidade pressupunham que a totalidade (a aglomeração urbana) devesse prevalecer sobre as partes (indivíduo) e a concepção cultural de cidade estar acima da material.

Howard é um jornalista que concebe um modelo de cidade (politizada), fruto de sua atuação profissional que o coloca em contato direto com a realidade social-proletária de Londres, que mesmo antes de infiltrar-se no meio urbanístico, como um novo paradigma, ganha as manchetes dos jornais, como forma de denunciar aquela condição degradante de vida originária do modo de produção capitalista-industrial. Portanto, há uma dimensão politizada de proposta de cidade de Howard, que está vinculada ao ambiente reflexivo em que desenvolveu seu pensamento.

\section{CAMiLlo SitTe (1843-1903)}

As concepções de Unwin e de Sitte são despolitizadas, principalmente a deste último, que constrói uma abordagem estética a partir de referências arqueológicas e do arcabouço acumulado pelo imaginário do planejamento urbano que servirá de apoio para suas propostas. O modelo cultural, contudo, opõe-se ao progressista, na medida em que a concepção de cidade passa a ser projetada rigidamente do ponto de vista populacional e sua extensão. Por esse motivo, o aparecimento do urbanismo como disciplina ocorre paralelamente ao desensua extensão. Por esse motivo, o aparecimento do urbanismo como discipling
volvimento de trabalhos teóricos que tinham como foco o desenho urbano.

Se do ponto de vista populacional e de sua extensão, o controle era rígido, o desenho urbano proposto 
pelos culturalistas seguirá uma orientação diversa, com forte caráter compósito arquitetônico medieval. Sitte critica a rigidez e falta de imaginação dos traçados repetitivos das propostas urbanas alemãs. Segundo ele, a importância dada às questões, como o tráfego e a infraestrutura, em detrimento das intervenç̃ões paisagísticas ambientais e morfológicas, era um dado da falta de imaginação dos traçados germânicos.

Ao citar os traçados germânicos, Sitte faz referência direta à Georges-Eugène Haussmann (1809 - 1891), conhecido como o Barão Haussmann, e que foi nomeado prefeito de Paris por Napoleão III. Haussman foi encarregado pelo Imperador de modernizar a cidade. $\mathrm{O}$ seu projeto de remodelação demoliu as antigas ruas, pequenos comércios e moradias da cidade e institui um planejamento de alinhamento retilíneo de grandes avenidas e bulevares, criando uma "estrela" com 12 vias amplas em volta do Arco do Triunfo até um dos extermos da Champs-Elysées.

O foco das intervenções de Haussmann foram executadas, principalmente, no casco antigo de Paris. Um tipo de modernização estratégica que contou com novos traçados, reformulação fundiária, criação de infraestrutura, equipamentos urbanos e espaços livres (áreas verdes), fundamentadas em três eixos principais, segundo Lamas (2014, p. 212): - Circulação fácil e cômoda dentro da cidade, indo de gare a gare, ou de bairro a bairro; - Eliminação da insalubridade e degradação dos bairros, arejando os densos interiores, estabelecendo uma imagem geral de modernidade, criando uma cidade com luz, espaço e arborização e uma nova arquitetura urbana; - Revalorização e reenquadramento dos monumentos, unidos através de eixos viários e perspectivas.

A racionalidade das intervenções de Haussmann negará o passado arquitetônico da capital francesa, retaIhando-a, segundo traçados que cortam a cidade com rotas que partiam de praças ou cruzamentos, unindo pontos da estrutura urbana. Das intervenções, surgiu uma cidade em que o quarteirão, tratado como consequênci natural das transformações, terá “(...) forma irregular, poligonal, retangular, triangular ou vai aproximar-se da forma de bloco, sendo então compacto (...)" e com vazios no seu interior (LAMAS, 2014, p. 214). Ao mesmo tempo, em que reconfigurava o centro antigo da cidade com esses novos traçados, Haussmann instituirá uma nova lógica de reparcelamento cadastral do solo urbano, a partir de três princípios elementares (LAMAS, 2014, p. 215): - Cada lote é definido por sua perpendicularidade à rua; - A divisória entre lotes corresponde à bissetriz do ângulo formado pelas ruas, ou seja, os ângulos dos triângulos formados pelos quarteirões se dividem por dois, formando lotes, sucessivamente, em parcelas congruentes.

Diversas funções são introduzidas nos interiores dos quarteirões pela elevação de equipamentos, tais como: serviços, pequenas indústrias, artesanato, armazéns e jardins, dentre outros. Em algumas regiões, os quarteirões triangulares serão entrecortados por galerias comerciais, que, paulatinamente, transformar-se-ão no novo paradigma de comércio, hoje transmutados em diversos países nos palacetes de consumo de mercadorias, denominados Shopping Centers.

Sitte elabora sua proposta em contraposição às intervenções racionalizantes que promoviam profundas rupturas com os elos que conectavam o presente ao passado das cidades. Suas soluções levam em consideração o caráter "humano" de uma cidade, ou seja, o espaço construído é fruto de relações sociais, de projeções artísticas do passado que produziram efeitos "(...) tão harmoniosos e que hoje só causam impressões enfadonhas e sem nexo" (CHOAY, 2011, p. 206). Dito de outra maneira, seu ponto de partida será a reinterpretação da cidade medieval, colocando, em segundo plano, intervenções que incorporassem, obrigatoriamente, questões, como o zoneamento, as infraestruturas, controle de densidades, via, por exemplo, concepções originárias da teoria de cidade-jardim e sua corolária Unidade de Vizinhança, índices urbanísticos ou a organicidade funcional de uma aglomeração.

Pelo fato de abrir mão de instrumentos que se mostraram - a despeito das críticas e conflitos sociais gerados -, eficientes para controlar o organismo urbano e a grande cidade, o receituário de Sitte enquadrou-se em pequenas sequências espaciais da malha urbana. Ele demonstrava enorme apreço pela morfologia das cidades medievais, a rua, a praça, o mercado, os edifícios singulares e quarteirões cortados por estreitas ruas passantes em dinamismo social e econômico. Os fatores que interferiam no traçado geral de uma planta de cidade medieval são vários: características físicas do local (relevo, clima, curso d'água), vontade humana, preço do solo, nível de riqueza dos habitantes, prestígio, procura por qualidade de vida. Esses fatores influirão muito nos pormenores históricos da criação e do desenvolvimento das cidades, tais como, desenho das ruas, formato do parcelamento do solo, densidade das construções, espaços verdes, equipamentos coletivos, dentre outros. É essa pequena escala que Sitte dominará e o movimento moderno assimilará, seletivamente, alguns de seus as-

pectos, como, por exemplo, a revitalidade medieval no desenho da cidade ou na composição da forma urbana. O estudo do passado é um procedimento metodológico adotado por Sitte como possibilidade de promover uma comunhão entre a técnica e a arte. Sua preocupação principal, ao produzir um exame do passado das cidades, era encontrar uma solução para o problema do seu presente histórico que pudesse satisfazer três condições básicas de qualquer intervenção urbana [...] livrar-nos do sistema moderno dos conjuntos, de casas regularmente alinhadas; salvar, na medida do possível, o que resta das cidades antigas; e aproximar sempre mais nossas criações, atuais do ideal dos modelos antigos. (SITTE apud CHOAY, 2013, p. 206).

Portanto, Sitte reexamina o processo construtivo e o uso dos espaços urbanos do passado e, paralelamente, processa um conjunto de observações que objetivavam reintroduzi-las nas dinâmicas modernas e ocupações do solo, que, no limite, também promoveriam ações de preservação do patrimônio histórico. Os locais públicos do passado (fórum, mercado, etc) perderam as suas referências originais de uso, mas podem representar um alento, enquanto uma referência monumental, para romper com a padronização da arquitetura urbana composta, em áreas residenciais, por um oceano de casas" (CHOAY, 2013, p. 206).

As praças dos mercados abertos - como referência de primeira ordem do teatro das cenas da vida pública -, tendem a enclausurarem-se em grandes mercados que ofuscam relações sociais que se pautam apenas pela lógica do consumo de mercadorias. Em inúmeros outros exemplos, que percorrem circuitos urbanos públicos que vão de Pompeia à Atenas, passando ainda por Roma, Sitte é incansável na descrição das características históricas-arquitetônicas e de uso dos espaços públicos ou prédios do passado que exprimem a essência cultural de um povo. Suas análises evidenciam a tessitura de uma nova cidade, formas de relações sociais construídas ao longo do tempo e que conferiram especificidades na forma de se "viver" a cidade. O urbanista irrompe críticas à "apologia da irregularidade", utilizada como argumento central às intervenções feitas por técnicos no início do século XX.

Segundo ele, a morfologia irregular típica de algumas regiões dessas cidades, como as praças, porém de um desenvolvimento histórico que se deu paulatinamente. A limosidade das práticas: a presença de um canal ou de uma trilha singrado em solo à forma mesmo de uma construção. A intencionalidade no desenho dessas formas, que asseguram impostos pela topografia do terreno, confere a esses espaços singularidades de um aspecto atrativo.

Portanto, metodologicamente, Sitte propõe que o plano desenhado de uma cidade ou, mais precisamente, possíveis intervenções pontuais no tecido urbano devam ser orientadas pelo plano vivido. A cidade moderna é o espaço da simetria e da proporção que, como um rolo compressor, esmaga a história e as redes sociais que se consolidaram no transcorrer dos séculos e que deixaram suas marcas visíveis no formato sinuoso das ruas ou na desproporção dos ângulos que formam uma praça.

O paradigma da simetria e da proporcionalidade transformou-se na pedra angular das propostas modernas de cidades e se espalha como uma reação em cadeia entre os arquitetos e urbanistas. A noção de simetria utilizada pelos arquitetos e modernistas é a que surgiu na Idade Média, a partir do momento em que os liceus de ofícios começaram a traçar desenhos de arquitetura e em que se principiou a preocupação, cada vez maior, com eixos de simetria, no sentido da semelhança da imagem à esquerda e à direita de uma linha principal que servisse de orientação. No entanto, para os gregos da antiguidade, proporção e simetria são a mesma coisa, embora apresentem uma única diferença do ponto de vista arquitetônico: "[...]a proporção é simplesmente uma relação agradável aos olhos, enquanto simetria na mesma relação expressa em números" (SITTE apud Choay, 2013, p. 213). No entanto, claramente, desde a renascença, os construtores empregavam os conceitos de proporção e simetria a partir de eixos nos planos dos edifícios e no desenho das cidades.

Sitte também faz referência aos impactos que a vida pública sofreu a partir das nuances arquitetônicas das cidades e, sobretudo, nas formas de comunicação social. Os acontecimentos, segundo o autor, passavam a ser contados pelos jornais, ao invés de debatidos nos espaços (praças) públicos. Essa transformação está também conectada ao desenvolvimento considerável (gigantismo) que as capitais atingiram, às dimensões clássicas das ruas e praças e aos inúmeros andares dos prédios que solapam a sensibilidade social e arquitetônica.

Além desse aspecto, o inchaço das cidades industriais, provocado, principalmente, pelos fluxos migratórios contínuos campo-cidade, gerou, do ponto de vista econômico, a produção capitalista (voltada para o mercado) do parcelamento do solo, constituindo-se em um dos fatores centrais no recrudescimento das desigualdades sociais urbanas. No entanto, reconhecemos que os engenheiros fizeram mudanças importantes na forma de se 
construir cidades modernas e que a saúde pública melhorou consideravelmente. Houve queda no coeficiente de mortalidade, mas, questiona Sitte: "Para obtê-los, será mesmo preciso eliminar toda a beleza das nossas cidades?" (SITTE apud CHOAY, 2013, p. 215).

Portanto, as reformas para introduzir uma nova dinâmica de ordenação das cidades modernas devem incluir: construção de praças, planos urbanísticos que privilegiem a arte, projetos de intervenção que levem em consideração as mudanças pelas quais as cidades passarão em um determinado período de tempo (projeção populacional futura que demandará investimentos na infraestrutura urbana) e o desenho da malha urbana deve se adaptar às desigualdades do terreno.

As praças devem ser a referência principal das relações sociais e, no limite, ser a força maior que conecta o homem ao local e que cria um sentimento de lar. As cidades devem elaborar planos de extensão, que, projetados em um arco temporal de cinquenta anos, poderão produzir cálculos aproximados do crescimento previsível da população de um bairro projetado e orientar estudos da circulação do gênero de habitação Nitidamente, Sitte faz uma escolha pela ferramenta "planejamento" para se municiar de informacões, suficientes e indispensáveis para prever a transformação pelas quais um bairro passará. Além da previsibilidade, a ser captada pelo planejador-urbanista, torna-se necessário determinar o local e o número de igrejas, escolas, prédios administrativos, dos mercados, dos jardins públicos em um tipo de zoneamento da extensão urbana.

\section{EBENEZER HOWARD (1850-1928)}

Entretanto, sem dúvida, assim como aponta Jacobs (2011), a vertente mais importante do urbanismo moderno foi criada por um jornalista, observador de Londres do final do século XIX, Ebenezer Howard. Da crueza londrina que tocou as retinas de Howard, metrópole industrial, repleta de bolsões de pobreza e cortiços e falta de zoneamento básico, surge um modelo que, em concepção, nega a urbanização, a própria cidade grande, complexa e dinâmica, ao eleger o bucolismo do campo reproduzido em cidadezinhas autossuficientes.

O solo filosófico em que Howard finca suas bases conceituais, portanto, é a criação de cidades autossuficientes, agrárias e agradáveis (com rígido controle populacional), divididas em zonas de igual rigidez e que produziriam cidadãos dóceis em uma vida comunitária. Esse modelo de cidade dialoga com o contexto em que Howard vivia e, sobretudo, com as experiências que vivenciou em sua trajetória na primeira metrópole industrial do planeta, Londres. Ao tentar produzir um modelo rígido de cidade, como fórmula de combate aos descaminhos encontrados nas metrópoles industriais, Howard preconiza o próprio "desmonte" das grandes aglomerações urbanas. A receita possui um fundamento: conter o crescimento das grandes cidades e repovoar a zona rura com um novo formato - cidade-jardim, onde os pobres poderiam voltar a viver em contato com a natureza.

O modelo proposto contaria com um cinturão agrícola e com indústrias, escolas, moradias e áreas verdes em territórios predeterminados. No centro da aglomeração, ficariam os estabelecimentos comerciais, esportivos e culturais, partilhados por todos. A administração pública cumpriria o papel de gerir (fiscalizar) o espaço, de modo a evitar a especulação imobiliária ou mudanças no uso da terra, orientados por interesses particulares ou também afastar a tentação de aumentar a densidade populacional, pressionando a malha urbana em direção de vetores de crescimento de interesse do mercado. A população máxima deveria ser de trinta mil habitantes que viveriam em uma sociedade política economicamente paternalista.

A cidade-jardim foi concebida como uma alternativa à cidade e, sobretudo, como uma solução para os problemas urbanos. Essa foi e é o alicerce de seu imenso poder atrativo como conceito de planejamento urbano. O cerne da proposta residia em lidar com as funções da cidade, separando-as de seus usos relativamente independentes. As funções distribuíram-se no território urbano entorno das áreas residenciais, subordinandoas. O comércio deveria proporcionar o fornecimento rotineiro e padronizado de mercadorias e atender a um mercado restrito. O planejamento, dos termos propostos por Howard, era um conjunto de ações estáticas que deveriam prever tudo o que fosse mecanismo para manter o desenho da cidade, suas funções territorialmente deveriam prever tudo o que fosse mecanismo para manter o desenho da cidade, suas funções territorialmente
localizadas e protegê-las de quaisquer alterações. Assim, em gênese, descarta a complexa e multifacetada vida cultural da metrópole. Não lhe interessavam questões, como segurança pública, configuração de ambientes para trocas de ideias entre os munícipes, o funcionamento político ou a criação de novas saídas econômicas nas grandes cidades. Portanto, Howard constrói um modelo de cidade que, réplica em diversas regiões do planeta com distintas adaptações, influenciará todo o planejamento urbano moderno. O sucesso de sua proposta está no fato de a sua teoria possuir um forte apelo prático, o que levou Howard, em 1899, a fundar a Associação das Garden-Cities e, em 1903, em Letchworth, a adquirir o primeiro terreno para construir sua proposta.
As primeiras realizações das cidades-jardins na Inglaterra foram confiadas a dois jovens arquitetos: B. Parker e Raymond Unwin. As ideias de Howard tomam forma nas três cidades inglesas, Letchworth (1904), Hanslead (1909) e Welwyn (1919), que deviam atuar como polos alternativos de desenvolvimento econômico e fixação populacional. Essas três cidades converteram-se depois em parâmetros na Europa e nos Estados Unidos, sendo absorvidas como proposta especialmente por Henry Wright e Clarence Stein.

\section{RAYMOND UNWIN (1863-1940)}

Raymond Unwin publicou os resultados das suas experiências na construção de Letchworth e Hamplead, no livro Town Planning in Practice, que, se constitui em um verdadeiro manual de como compor sua cidade-jardim. Não são, portanto, apenas as teorizações de Howard que projetarão sua proposta para além das fronteiras inglesas, mas, sobretudo, a sua conjunção com os princípios de desenho urbano de Unwin. É possível, segundo Lamas (2014), identificar algumas distinções entre os conceitos de Howard e as morfologias urbanas utilizadas por Unwin e Parker nos três exemplos citados de cidades-jardim. A despeito de o cerne da proposta de cidade-jardim ainda continuar sendo a criação de um ambiente dominado por superfícies arborizadas, plantadas e ajardinadas, que permitiam o acesso visual e físico a todos os espaços urbanos, Unwin expande essa concepção original, introduzindo-lhe modificações que dialogam com as ideias modernas da arquitetura. Como se fosse um minueto do que será, mais tarde, a unidade de vizinhança, Unwin procura elaborar pequenas aglomerações humanas.

Segundo Unwin, as práticas sociais e algumas funções da rua como ambiente de convívio e de acesso aos edifícios deslocam-se para essa área, denominada empasse (close), que passava a ser uma categoria intermediária entre os espaços públicos da rua e o espaço privado das habitações (um espaço semipúblico para as relações sociais entre vizinhos). Essa possibilidade de releitura da proposta original de Howard de cidade-jardim será produzida, inicialmente, por Clarence Stein e Henri Wright na concepção de um novo esquema para os bairros de subúrbio. Radburn, um bairro de Nova Jersey, Estado Unidos, é a proposta de um residencial modelo (1929) em que os jardins e espaços abertos eram predominantes.

O sistema pensado para Radburn resolvia a incompatibilidade de convivência entre automóveis e cidadãos, pois permitiu acesso direto à habitação, isolando-a dos espaços coletivos livres e de instalações voltadas para práticas esportivas. Os automóveis circulariam até acessar as garagens residenciais (Service Road), um sistema de footpaths que permitiria a circulação de pedestres e o convívio social nas áreas verdes (parques e jardins).

As propostas urbanísticas e culturalistas, aqui apresentadas em seus principais expoentes, também servirão de embasamento para Anhaia Mello no enfrentamento dos problemas da conturbe paulistana, advindos, principalmente, da alta concentração industrial. Além de provocar um desequilíbrio com relação aos outros entes federativos, a cidade de São Paulo agonizava diante do seu inchaço desordenado por ser um polo gerador de empregos importantes no Brasil. Portanto, Anhaia Mello defende uma prática de reforço das cidades pequenas e médias, em detrimento do crescimento desmedido da metrópole e empunha a bandeira da descentralização industrial em um conjunto ou, nas palavras urbanísticas, em uma federação de pequenas cidades que garantiriam o rígido controle das funções das cidades e da população, assim como concebeu Howard, ao criar as cidadesjardins como alternativa a Londres em torno de São Paulo. No entanto, essas cidades deveriam incorporar o solo teórico urbanístico consolidado internacionalmente e que fornecia um conjunto de recomendações sobre a esfera municipal, elaboradas pela primeira geração de urbanísticas ingleses, progressistas e culturalistas, tais como: 1 - limitar o crescimento urbano; 2 - rearticular a população em cidades-jardins com subordinação das funções urbanas à área residencial; 3 -regulare limitar o crescimento de todas as cidades e vilas daárea regional paulistana; 4 - criar normas que regulem, democraticamente, a forma de parcelamento, uso e ocupação do solo urbano.

As novas cidades, em síntese, deveriam possuir uma morfologia de seu desenho que se fundamentasse em três quesitos: 1 - cordão verde, para limitação do tamanho da cidade; 2 - a incorporação do conceito de unidade de vizinhança (no Brasil, reatualizado por Niemeyer e Costa como superquadras), mais afilado às alternativas concebidas por Clerence Stein para o plano de Radburn, anteriormente descrito, e que permitiriam uma convivência pacífica do automóvel com o cidadão.

Esses são os principais fundamentos utilizados por Anhaia Mello durante sua longa trajetória acadêmica-profissional. Na próxima seção, analisaremos o processo de consolidação de um campo de pesquisa em planejamento territorial na Faculdade de Arquitetura e Urbanismo da Universidade de São Paulo - FAUUSP e o caminho criativo seguido por um conjunto de arquitetos-urbanistas e planejadores, na sua difusão entre 
os municípios paulistas.

\section{CONSIDERAÇõES FINAIS}

O processo reflexivo percorrido por Anhaia Mello revelo-nos uma intrincada rede de contatos políticos, acadêmicos e profissionais voltados para a análise da problemática urbana da primeira metade do século XX A realidade paulistana desse período instigou o urbanista na elaboração de propostas inspiradas, basicamente, em duas vertentes urbanísticas mundiais: a progressista e a culturalista. O acelerado processo de desenvolvimento urbano da capital paulista conectou à sua realidade aos princípios elaborados por urbanistas que pensaram soluções para as metrópoles industriais norte americanas e europeias. Anhaia Mello elabora um refinado pensamento urbanístico que (re)significou propostas de cidades voltadas para o ordenamento na produção, ocupação e utilização do solo urbano.

A profissão de arquiteto, nesses termos, deveria possibilitar a inserção de atores no mercado de trabalho que pudessem elaborar e implementar novos modelos de cidades e/ou criar intervenções nas realidades urbanas consolidadas via regulamentação de instrumentos de politica urbana, como 0 plano diretor. Anhaia Mello atuou efetivamente na institucionalização do exercício da profissão do arquiteto - que competia com o prático - e na formulação de grade curricular, com a fundação da FAUUSP em 1948, que pudesse originar o perfil profissional do almejado "arquiteto-planejador".

A produção intelectual de Anhaia Mello analisada revela que o urbanista buscou soluções na arquitetura moderna progressista e culturalista, fundamentalmente, ao elaborar a sua proposta de cidade e de desenvolvimento urbano. Os ciclos de palestras e artigos produzidos pelo urbanista-pesqusiador, localizam o seu pensamento em um esforço racionalizante das estruturas urbanas voltadas, por exemplo, para a comunicação, com a criação de extensas artérias para atender ao fluxo de transportes nas metrópoles industriais, como São Paulo

O pensamento de Anhaia Mello, portanto, situa-se no momento em que urbanistas recriavam o modelo de intervenção na malha urbana para dar resposta ao desordenado crescimento das metrópoles. A localização humana nas malhas urbanas industriais passa a ser o objeto reflexivo do urbanista brasileiro que, por sua vez, recorre a um conjunto de pensadores americanos e europeus. Anhaia Mello organiza essas propostas e elabor um quadro normativo que, no Brasil, será aglutinado no que denominamos Planos Diretores, difundidos pelo interior do Estado de São Paulo pelo CEPEU.

A vertente progressista, que se organiza fortemente a partir dos CIAM's, elaborou propostas para institui princípios à separação das funções urbanas, mas tarde denominado zoning, amplamente difundido no Brasil. Tony Garnier e sua obra Uma cidade industrial, são os ícones desse momento do urbanismo mundial. A habitação operária também surge como um tema de destacada importância, pois eram fundamentais para o controle e "higienização" da mão de obra. A setorização e o controle urbanos são concepções presentes desde o pensamento do inglês Ebenezer Howard, com estreito diálogo com a necessidade de arborização e higienização da malha urbana. Walter Gropius, por sua vez, fornecerá para Anhaia Mello uma reflexão sobre a tipologia das construções e sua disposição na malha urbana, de acordo com códigos de ocupação que orientariam a produção e a utilização do solo urbano. Grupius, e em certa medida Anhaia Mello, pensa a cidade como um conjunto de ruas que conectavam células, de caráter econômico ou residencial, e que poderiam, segundo suas concepções, orientar e normatizar o desenvolvimento urbano.

Le Corbusier, conforme apontamos no artigo, conduzirá os olhares de Anhaia Mello não apenas pela necessidade de classificação das funções urbanas e multiplicação de espaços verdes, mas, e sobretudo, na construção de uma visão arquitetônica da cidade, considerada como um organismo urbano. A questão social das cidades industriais passou a ser encampada pelas administracões municipais e, sem dúvida, Clarence Stein, com seu Plano para Radburn de 1929, consolida o conceito de unidade de vizinhança ao tentar resolver a incompatibilidade entre automóveis e cidadãos. Além desse aspecto, a unidade de vizinhança objetivava restabelecer as relações sociais entre os vizinhos, que tendiam a se degradar nos formatos de ocupação do solo impostos pela metropolização das cidades. Anhaia Mello capta a ideia central da unidade de vizinhança e a utiliza como fórmula para o controle populacional e de extensão territorial das unidades habitacionai elaboração de planos diretores.

O modelo culturalista, como afirma Choay (2013), influenciará diversas escolas urbanísticas que partirão

dos princípios elaborados por Ebenezer Howard de cidade jardim. A proposta nuclear consistia em um diferente modelo de organização social, econômica e territorial, com rígido controle populacional.

Camillo Sitte e Raymond Unwin despolitizaram a proposta de Howard ao introduzirem uma abordagem estética a partir de referências arqueológicas que, por sua vez, orientariam a prática de planejamento urbano. A concepção de cidade passa a ser projetada rigidamente, do ponto de vista populacional e de extensão. O desenho urbano proposto pelos culturalistas seguirá uma orientação diversa, com traços compósitos modernos e medievais. Anhaia Mello, em certa medida, preocupava-se com essas questões paisagísticas ambientais e morfológicas da cidade, com o rígido controle populacional, somadas às orientações da corrente progressista voltadas para a organização do tráfego e da infraestrutura urbana. Portanto, seu pensamento poderia ser classificado como generalista, mas que propunha o enfrentamento dos problemas da conurbe paulistana, advindos da concentração industrial, por meio da desconcentração industrial em um conjunto de cidades federadas com rígido controle das funções e da população.

REFERÊNCIAS

BENJAMIN, W. Baudelaire e a modernidade. Belo Horizonte: Autêntica Editora, 2015.

CHOAY, F. O urbanismo: utopias e realidades. São Paulo: Perspectiva, 2013.

Difuro W. A industrialização de São Pa

HOWARD, E, S. Cidades-jardins de amanhã. Tradução de Marco Aurelio Lagonegro. São Paulo : Hucitec, 1996.

JACOBS, J. Morte e vida de grandes cidades. São Paulo: Editora WMF Martins Fontes, 2011.

LAMAS, J. M. R.G. Morfologia urbana e desenvolvimento

NEVES DA ROCHA FILHO, G. Gustavo Neves da Rocha Filho: entrevista [9 de agosto de 2011]. Entrevistador: Rodrigo Alberto Toledo. São Paulo - SP: 2011. 1 arquivo digital VOICE002.MP3. Entrevista concedida ao professor aposentado da FAU-USP e elaborador do primeiro Plano Diretor da cidade de Araraquara à pesquisa de doutorado "Trajetórias do planejamento urbano no município de Araraquara: centralismo decisório ou participação?”.

ROCHA FILHO, G. N. Relatório final do Plano Diretor de Araraquara. Araraquara, São Paulo: 22 de dezembro de 1963 .

TOLEDO, R. A., KERBAUY, M. T. M.. O ensino e a pesquisa de planejamento territorial em São Paulo: a ficção e a realidade das políticas públicas urbanas da primeira metade do século XX. CaderNAU- Cadernos do Núcleo de Análises Urbanas, v.9, n. 1, 2016.

TOLEDO, R. A. Trajetórias Do Planejamento Urbano. São Carlos-SP: Rima Editora, 2013.

TOLEDO, R. A. Contribuições de Anhaia Mello ao urbanismo paulistano: de Ebenezer Howard à Escola de Chicago. Pós - Revista do Programa de Pós-graduação em Arquitetura e Urabnismo da FAUUSP Universidade de São Paulo, Faculdade de Arquitetura e Urbanismo. Comissão de Pós-Graduação - São Paulo: FAUUSP. V.1 (1990-) 